\title{
FLORISTIC AND HABITAT VARIABILITY, NATURE AND ENERGY VALUE OF SELECTED SEDGE COMMUNITIES
}

\author{
MieczysŁaw Grzelak, Eliza Gawee, BogusŁawa Waliszewska, Magdalena Janyszek, \\ Dorota Wrońska-Pilarek, Maciej Murawski, AgnieszKa Knioła
}

\begin{abstract}
M. Grzelak, M. Murawski, A. Knioła, Department of Grassland and Natural Landscape Sciences, Poznań University of Life Sciences, Dojazd 11,60-632 Poznań, Poland, e-mail: grzelak@up.poznan.pl

E. Gaweł, Institute of Soil Science and Plant Cultivation - State Research Institute, Czartoryskich 8, 24-100 Puławy, Poland, e-mail: Eliza.Gawel@iung.pulawy.pl

B. Waliszewska, Section of Wood Chemistry and Forest Products, Poznań University of Life Sciences, Wojska Polskiego 38/42, 60-627 Poznań, Poland, e-mail: bwaliszewska@up.poznan.pl

M. Janyszek, Department of Botany, Poznań University of Life Sciences, Wojska Polskiego 71 C, 60-625 Poznań, Poland, e-mail: carexmag@up.poznan.pl

D. Wrońska-Pilarek, Department of Forest Botany, Poznań University of Life Sciences, Wojska Polskiego 71 E, 60-625 Poznań, Poland, e-mail: pilarekd@up.poznan.pl
\end{abstract}

(Received: September 30, 2016. Accepted: December 21, 2016)

\begin{abstract}
AвSTRACT. The aim of this study was to determine floristic diversity, the chemical composition, nature value and energy value of selected sedge communities in view of habitat conditions in the Noteć valley. This study was based on a total of 46 relevés prepared according to Braun-Blanquet.

The identified communities were represented by common plant associations, both natural or semi-natural. They comprised mainly vegetation of meadows excluded from agricultural use, on fresh and partly moist and very moist soils, of weak acid and neutral reaction. Analysed communities had moderate or high nature value. Sedges and Cyperaceae predominated in their structure, with the greatest share of Caricetum lasiocarpae $(76 \%)$ and the lowest share of Caricetum distichae $(44.6 \%)$. No Fabaceae were reported in any of the two plant associations, while herds were found in all associations. The greatest higher heating value and lower heating value were found for communities with Carex lasiocarpa and Carex disticha.
\end{abstract}

KeY WORDS: floristic diversity, habitat, rush communities, energy value

\section{INTRODUCTION}

Sedges (Carex L., Cyperaceae) are a group of plants found very commonly worldwide. This genus comprises approx. 2000 species covering various habitats and found in diverse plant communities, representing differing levels of substrate moisture contents, at the same time exhibiting considerable tolerance to variation in habitat conditions (Egorova 1999). Due to the broad habitat spectrum many sedge species constitute a significant component of certain plant communities, occurring in them with high stability and frequency and occasionally forming their own communities, in many cases in the form of single-species phytocenoses covering large areas or with a slight admixture of representatives of other plant species. Next to grasses, sedges are plants highly frequently found in many meadow and pasture communities in inundation zones and in local depressions, in overgrowing small water bodies, among moist meadows. Also in utilised agricultural areas sedges are found both as single specimens and forming dense swards, and they are dominants throughout the area subjected to such land use (DenIsIuk 1968, 1980). Frequently in river valleys numerous communities with the dominance of species from the genus Carex, which are characterised by exceptional viability and very high stability, they are very well developed and most frequently a moderate floristic richness. At the same time they frequently serve productive functions, oc- 
casionally being of great value from the economic point of view.

Communities with a share of sedges also exhibit many valuable non-productive functions in the natural environment (GRZeLAK et al. 2011). They are living and breeding spaces for many animal species, particularly avifauna (KRUPA 2000, CZYŻ et al. 2011), and have aesthetic and landscape value (TrzAsKoś et al. 2005). Identification of their natural and utility value is crucial for the assessment of the natural environment and as such contributes to the necessary spatial planning and protection of species richness of these biocenoses (GrzelaK et al. 2014). Attractiveness of many such areas, including that analysed in this study, is connected first of all with their high degree of naturality and a well maintained marsh ecosystem with a mosaic pattern of flooded areas and marsh habitats (Jonsson \& MaLmQvist 2000, RiIs \& BIGGs 2003).

Sedge communities are also sources of biomass, a potentially valuable raw material for the production of pellets and briquettes, used as energy material (Rogalski et al. 2008, GrZelaK et al. 2010, 2014). NiedzióŁKA \& Zuchniarz (2006) and WaliszewsKa et al. (2013) stated that some sedge species meet certain requirements imposed on energy materials, while НАRкот et al. (2007) was of an opinion that under climatic conditions of Central Europe one of the most advantageous measures will be connected with the energy use of biomass from grass and sedge straw. The share of representatives from the genus Carex is also of particular importance in reservoirs of organic sediments formed among other things from aboveground and underground shoots of sedges. It needs to be mentioned here that in recent years not only specific plant species are treated as a valuable renewable energy source, but such an approach is also applied to habitats related with these species, treated as biomass, including peat deposits (KovAcOva \& Schreiber 2003, Kuklova et al. 2005, Czyż et al. 2011, VirTANEN \& VAlpola 2011).

A considerable role in the case of collection of the energy material is played by plant height. This is crucial in the case of representatives of tall species, forming dense swards and characterised by a high increment in biomass during the vegetation season. Such properties are exhibited e.g. by C. riparia, C. paniculata and C. appropinquata forming more or less dense swards of tall sedge rushes from the class Phragmitetea. An additional advantage is also connected with their occurrence in the wild and potential for self-regeneration of phytocenoses, with no need for sod seeding. Many sedge species forming their plant communities are runner species of rapid growth, frequently remaining in the vegetative phase throughout the entire vegetative season, such as e.g. C. acuta or species, which representatives form large clusters with a considerable leaf mass, e.g. C. pani- culata. Another important characteristic of potential energy crops is their great lower heating value, limited soil requirements and high resistance to diseases and pests. Earlier studies conducted in this respect also confirmed the value of sedges as alternative, renewable energy sources (WALISZEWSKA et al. 2013).

In Poland, as well as other EU countries, a strategy has been adopted to create a more innovative and low-emission economy, combining sustainable agriculture, food safety and sustainable use of renewable resources for industrial purposes, at a simultaneous protection of biological and environmental diversity (Strategia... 2001, Ustawa... 2003). In the climate agreement of UN nations, concluded in Paris on 12 December 2015, which is to enter into force since 2020 , an increasing importance is placed on the generation of energy from renewable sources. This is necessary to no longer rely on the limited resources of fossil fuels.

The aim of this study is to determine floristic diversity, habitat conditions, nature and energy value of selected sedge communities in view of diverse habitat conditions in the Noteć valley

\section{MATERIAL AND METHODS}

Analyses were conducted in seven plant communities of sedge rushes and communities with the dominance of sedges, found in diverse habitats in the Noteć valley and belonging to three phytosociological classes: Phragmitetea R.Tx. et Prsg 1942 (low sedge lowmoor and transition peatbogs) - four communities of Scheuchzerio-Caricetea nigrae (Nordh. 1937) R.Tx. 1937 (rushes) - two communities, and Festuco-Brometea Br.-Bl. et R.Tx. 1943 (xerothermic swards) - one community.

Materials for analyses were collected in the years 2009-2013, in the course of geobotanical surveys conducted in the Wielkopolska region. The basis for the characteristics of floristic diversity in the investigated communities comprised 46 relevés, which were performed according to Braun-Blanquet (Braun-Blanquet 1964). Using the floristic data collected in field analyses syntaxa were identified, which were classified to the phytosociological system in accordance with the study by MatusZKIEWICZ (2013). Nomenclature of communities was based on Matuszkiewicz (2013).

The study on floristic diversity comprised analyses of the species composition, i.e. botanical structure (in \%), the total number of species found in the community and the calculation of the Shannon-Wiener diversity index: $\mathrm{H}^{\prime}=-\sum\left(\mathrm{p}_{\mathrm{i}} \times \log \mathrm{p}_{\mathrm{i}}\right)$ (KREBS 2001).

The current condition of habitat conditions was assessed based on the values of indicator factors according to Ellenberg (ElLENBERG et al. 1992): F - moisture content, $\mathrm{R}$ - reaction, and $\mathrm{N}$ - nitrogen content 
in the soil. Communities were subjected to natural valuation, in which nature value was assessed in a 10-point scale: the mean valuation factor, nature value and the valuation class according to OśwIT (2000).

To perform the analyses in order to determine higher heating value whole aboveground parts of plants - leaves and stems, which were ground after drying and analysed. Results reported in the study are means from three measurements and they were calculated in relation to dry mass of the raw material. Analyses of the chemical composition of the raw material were conducted according to the standard PN-92/P-50092 for plant material and the following parameters were determined: moisture content using the gravimetric method, and contents of minerals determined to the standards DIN 51731.

Analyses of higher heating value were performed according to the standard PN-81/G-04513 in a ZKL4 calorimeter, dedicated to measurements of higher heating value $\left(\mathrm{Q}_{\mathrm{s}}^{\mathrm{a}}\right)$ of solid fuels.

\section{RESULTS}

Within the seven surveyed plant communities a total of 109 vascular plant species were reported. Within the class Phragmitetea the largest number of species was recorded in the association Caricetum paniculatae (38), while it was lowest in C. appropinquatae (15). In Scheutzerio-Caricetum nigrae a greater number of species was found in C. flavae (36), while it was markedly lower (24) in C. lasiocarpae. Investigated communities from the class Festuco-Brometea were characterised by intermediate values of the number of species (27). Thus the two vegetation phytocenoses richest in species were C. paniculatae and C. flavae.

Generally it may be stated that in the investigated phytocenoses sedges and Cyperaceae predominated, found in all the analysed communities. In turn, their share was largest in C. lasiocarpae amounting to $76.8 \%$ and in C. ripariae $(67.2 \%)$, whereas it was lowest in C. distichae at $44.6 \%$. Grasses as well as herbs and weeds are also groups of plants found in all the associations, while the greatest percentage share of grasses was recorded in C. distichae $(33.1 \%)$ and the community with Carex praecox $(31.2 \%)$, while it was markedly lowest in C. ripariae $(4.8 \%)$. The share of herbs and weeds in the investigated phytocenoses is the lowest in C. lasiocarpae (13.5\%), with the others it was more or less similar. In two investigated associations no legumes were reported, which percentage share was lowest among all the investigated groups of plants (Table 1).

The calculated value of moisture content factor (F) for six investigated communities was characterised by the relatively limited diversification and ranged from 7.1 to 8.2 (Table 2). This shows that they are localities ranging from moist to wet, while the largest moisture content factor for the subsoil was found for C. ripariae (8.2). In the case of communities with Carex praceox the lowest values of the factor were recorded (6.2); however, they were also classified as moist, with a tendency towards fresh.

The range of the scale of reaction $(\mathrm{R})$ - the degree of soil acidification in the analysed phytocenoses was relatively comparable for five analysed communities and it ranged from 4.9 (C. distichae) to 5.8 (C. flavae). Only in the case of $C$. appropinquatae and communities from Carex praecox it deviated slightly from these values (6.8 and 6.9, respectively). However, all the calculated indexes classify the investigated communities from moderately acid and weak acid to neutral (Table 2).

Most analysed soils were moderately abundant in nitrogen (4.2 to 5.5), only in C. appropinquatae and in communities with Carex praecox it was large (5.9 and 6.8) (Table 2).

Analysed communities varied in terms of their nature value (Table 3 ). The mean valuation factor ranged from 2.4 in the community C. flavae to 3.9 in C. lasiocarpae, which generally classified the investigated communities in valuation classes from $\mathrm{V}$ to VIII. Based on the valuation according to OśwIT

Table 1. Floristic diversity in analysed communities (KREBS 2001)

\begin{tabular}{|c|c|c|c|c|c|}
\hline \multirow[b]{2}{*}{ Community } & \multirow[b]{2}{*}{ Total number of species } & \multicolumn{4}{|c|}{ Share in vegetation cover $(\%)$} \\
\hline & & sedges and Cyperaceae & legumes & grasses & herbs and weeds \\
\hline \multicolumn{6}{|c|}{ ChCl. Phragmitetea - communities of tall and low sedge rushes } \\
\hline Caricetum appropinquatae & 15 & 45.5 & 5.2 & 22.4 & 26.9 \\
\hline Caricetum distichae & 28 & 44.6 & 2.4 & 33.1 & 19.9 \\
\hline Caricetum paniculatae & 38 & 47.9 & 3.5 & 18.9 & 32.7 \\
\hline Caricetum ripariae & 28 & 67.2 & - & 4.8 & 28.0 \\
\hline \multicolumn{6}{|c|}{ ChCl. Scheuchzerio-Caricetea nigrae - low sedge communities } \\
\hline Caricetum flavae & 36 & 54.4 & 2.9 & 13.8 & 28.9 \\
\hline Caricetum lasiocarpae & 24 & 76.8 & 0.8 & 8.9 & 13.5 \\
\hline \multicolumn{6}{|c|}{ ChCl. Festuco-Brometea - communities of xerothermic swards } \\
\hline Carex praecox community & 27 & 45.2 & - & 31.2 & 23.6 \\
\hline
\end{tabular}


Table 2. Valuation of habitat conditions according to Ellenberg (ELLENBERG et al. 1992)

\begin{tabular}{|c|c|c|c|c|c|c|}
\hline \multirow{2}{*}{ Community } & \multicolumn{6}{|c|}{ Mean values of Ellenberg indexes } \\
\hline & value $\mathrm{f} F$ & $\begin{array}{l}\text { soil moisture } \\
\text { content }\end{array}$ & value of $R$ & soil reaction & value of $\mathrm{N}$ & $\begin{array}{l}\text { nitrogen content } \\
\text { in soil }\end{array}$ \\
\hline \multicolumn{7}{|c|}{ ChCl. Phragmitetea } \\
\hline Caricetum appropinquatae & 7.7 & moist to wet & 6.8 & weak acid to neutral & 5.9 & abundant \\
\hline Caricetum distichae & 7.6 & moist to wet & 4.9 & moderately acid & 5.5 & moderate \\
\hline Caricetum paniculatae & 7.1 & moist & 5.1 & moderately acid & 4.2 & moderate \\
\hline Caricetum ripariae & 8.2 & wet & 5.3 & moderately acid & 5.3 & moderate \\
\hline \multicolumn{7}{|c|}{ ChCl. Scheuchzerio-Caricetea nigrae } \\
\hline Caricetum flavae & 7.9 & wet & 5.8 & $\begin{array}{l}\text { moderately acid to } \\
\text { weak acid }\end{array}$ & 5.5 & moderate \\
\hline Caricetum lasiocarpae & 7.8 & moist to wet & 5.3 & moderately acid & 4.8 & moderate \\
\hline \multicolumn{7}{|c|}{ ChCl. Festuco-Brometea } \\
\hline Carex praecox community & 6.2 & moist to fresh & 6.9 & weak acid to neutral & 6.8 & abundant \\
\hline
\end{tabular}

Legend: $\mathrm{F}$ - moisture content index, $\mathrm{R}$ - soil reaction index, $\mathrm{N}$ - soil nitrogen content.

(2000), it may be stated that they are communities with medium, moderate and high nature value, while only one, i.e. C. lasiocarpae had very high nature value of valuation class VIII.

Some of the communities form relatively monotonous aggregations of one species, of low structural diversity, with hydrophilous and hydrophilic vegetation. Vegetation in these communities is frequently naturally developed from various classes (TRZASKoś et al. 2005). Due to the natural or semi-natural character of habitats, these communities are typically characterised by richness of flora, although some phytocenoses are poor in species and vary in their facies (Krupa 2000, Grzelak et al. 2014). Swards in some communities, with the decreasing anthropopressure are characterised by greater nature value. They may be sources of herb plants and having a unique microclimate and natural landscape value they have recreation and tourist potential.
Plant material of potential value for energy generation purposes has to meet certain criteria. The most important thermal and physical parameters of biomass include heat of combustion and calorific value. These parameters depend first of all on the chemical composition and moisture content of the material. Results of these studies indicate high and satisfactory heat of combustion value indexes from the point of view of energy generation purposes in the case of material coming from five communities (from 19000 to $19876 \mathrm{~J} / \mathrm{g}$ ) and it was slightly lower for $C$. ripariae and communities from Carex praecox (17 790 and $17980 \mathrm{~J} / \mathrm{g}$, respectively). There are comparable to the results reported by WaLISZEWSKA et al. (2013) for selected sedge species. It needs to be stressed that in the case of sedges the lowest index of heat of combustion was found for $C$. ripariae. In the case of calorific value also $C$. ripariae and communities with Carex praecox had the lowest values amounting to 16

Table 3. Nature value in reported plant communities according to OśwIT (2000)

\begin{tabular}{|c|c|c|c|c|}
\hline \multirow{2}{*}{ Community } & \multicolumn{4}{|c|}{ Nature value (Lwp) } \\
\hline & mean valuation number & valuation class & nature value & ${ }^{*} \mathrm{H}^{\prime}$ \\
\hline \multicolumn{5}{|c|}{ ChCl. Phragmitetea } \\
\hline Caricetum appropinquatae & 3.6 & VII & high & 2.1 \\
\hline Caricetum distichae & 3.0 & $\mathrm{~V}$ & average moderate & 1.8 \\
\hline Caricetum paniculatae & 3.4 & VI & moderately high & 1.5 \\
\hline Caricetum ripariae & 3.6 & VII & high & 1.9 \\
\hline \multicolumn{5}{|c|}{$\mathrm{ChCl}$. Scheuchzerio-Caricetea nigrae } \\
\hline Caricetum flavae & 2.4 & IV & moderate & 1.6 \\
\hline Caricetum lasiocarpae & 3.9 & VIII & very high & - \\
\hline \multicolumn{5}{|c|}{ ChCl. Festuco-Brometea } \\
\hline Carex praecox community & 2.8 & $\mathrm{~V}$ & average moderate & 1.9 \\
\hline
\end{tabular}

${ }^{*} \mathrm{H}^{\prime}$ - floristic diversity index according to Shannon-Wiener. 
Table 4. Characteristics of energy values of sedge communities

\begin{tabular}{|c|c|c|c|c|c|}
\hline \multirow[b]{2}{*}{ Community } & \multicolumn{5}{|c|}{ Contents of components } \\
\hline & $\begin{array}{l}\text { moisture content } \\
(\%)\end{array}$ & $\begin{array}{c}\text { ash } \\
(\mathrm{g} \cdot \mathrm{kg}-1 \mathrm{~s} . \mathrm{m} .-\mathrm{DM})\end{array}$ & minerals (\%) & $\begin{array}{l}\text { heat of combustion } \\
(\mathrm{J} / \mathrm{g})\end{array}$ & $\begin{array}{l}\text { calorific value } \\
(\mathrm{kJ} / \mathrm{kg})\end{array}$ \\
\hline \multicolumn{6}{|c|}{ ChCl. Phragmitetea } \\
\hline Caricetum appropinquatae & 7.1 & 7.5 & 7.3 & 19000 & 17280 \\
\hline Caricetum distichae & 6.9 & 7.1 & 6.7 & 19640 & 17930 \\
\hline Caricetum paniculatae & 7.5 & 8.2 & 6.8 & 19450 & 17370 \\
\hline Caricetum ripariae & 7.5 & 8.6 & 8.3 & 17790 & 16040 \\
\hline \multicolumn{6}{|c|}{ ChCl. Scheuchzerio-Caricetea nigrae } \\
\hline Caricetum flavae & 6.8 & 6.8 & 5.1 & 19450 & 18754 \\
\hline Caricetum lasiocarpae & 7.9 & 7.9 & 6.4 & 19876 & 17987 \\
\hline \multicolumn{6}{|c|}{ ChCl. Festuco-Brometea } \\
\hline Carex praecox community & 8.1 & 8.1 & 7.9 & 17980 & 16040 \\
\hline
\end{tabular}

040 and $16079 \mathrm{~kJ} / \mathrm{kg}$. The recorded values are comparable to those from a study by НАRкот et al. (2007) and much higher than values recorded by ROGALSKI et al. (2005). Other significant parameters included moisture content of combusted material and the amount of ash produced in the combustion process, which were also comparable to the results presented by WALISZEWSKA et al. (2013).

\section{CONCLUSIONS}

1. In selected sedge communities sedges and Cyperaceae predominate, which share was greatest in Caricetum lasiocarpae amounting to $76.8 \%$, while it was lowest in C. distichae at $44.6 \%$. In two associations no legumes were reported, while herbs and weeds were the groups of plants found in all analysed associations.

2. Sedge communities found in the Noteć valley form valuable ecosystems of medium, moderate and high, and in the case of $C$. lasiocarpae very high nature and landscape value.

3. Investigated sedge communities were found on fresh, moist to wet soils, with a reaction from moderately acid and weak acid to neutral, where abundance in nitrogen was moderate and high.

4. The greatest value of heat of combustion and calorific value were recorded for the material coming from C. lasiocarpae and C. distichae. The observed values cause the material can be considered good energy raw material.

\section{REFERENCES}

Braun-Blanquet J. (1964): Pflanzensociologie. Grundzüge der Vegetationskunde. Springer, Vien.

Czyż H., Kitczak T., Sarnowski A., Karasiuk M. (2011): Użytkowe, przyrodnicze i energetyczne walory przymorskich użytków zielonych. Rocznik Ochrona Środowiska 13: 1055-1068.

Denisiuk Z. (1968): Wartość gospodarcza ważniejszych gatunków turzyc w Polsce. Prace Komis- ji Nauk Przyrodniczych i Komisji Nauk Leśnych PTPN 24: 93-122.

Denisiuk Z. (1980): Łąki turzycowe Wielkopolski. PWN, Warszawa-Kraków.

Egorova T.V. (1999): The sedges (Carex L.) of Russia and adjacent states (within the limits of the former USSR). Chemical-Pharmaceutical Academy, Saint Louis.

Ellenberg H., Weber H.E., Dull R., Wirth V., WerNeR W., Paulissen D. (1992): Zeigerwerte von Pflanzen in Mitteleuropa. Scripta Geobotanica 18: 5-258.

GRZELAK M. (2010): Wartość gospodarcza biomasy szuwarów wielkoturzycowych $z$ ekologicznych użytków zielonych. Journal of Research and Applications in Agricultural Engineering 55(3): 95-98.

Grzelak M., Gawee E., Janyszek M., Diatta J.B., GaJEWSKI P. (2014): The effect of biotope and land use on floristic variation, nature and economic value of marsh sedge rushes. Journal of Food, Agriculture and Environment 12(2): 1201-1204.

Grzelak M., Waliszewska B., Sieradzka A., SpeakDźwigata A. (2011): Ekologiczne zbiorowiska łąkowe $z$ udziałem gatunków $z$ rodziny turzyc (Carex). Journal of Research and Applications in Agricultural Engineering 56(3): 122-126.

Grzelak M., Waliszewska B., Speak-Dźwigata A. (2010): Wartość energetyczna peletu $z$ łąk nadnoteckich ekstensywnie użytkowanych. Nauka Przyroda Technologie 4, 1\# 11.

Harkot W., Warda M., Sawicki J., Lipińska H., WyeuPeK T., Czarnecki Z., Kulik M. (2007): Możliwości wykorzystania runi łąkowej do celów energetycznych. Łąkarstwo w Polsce (Grassland Science in Poland) 10: 59-67.

Jonsson M., Malmqvist B. (2000): Ecosystem process rate increases with animal species rich-ness: evidence from leaf-eating, aquatic insects. Oikos 89: 519-523.

Kovačova M., Schreiber B. (2003): Aboveground biomass, energy content and phenology of Veronica officinalis L. (Scrophulariaceae) population under 
different canopy density of beech stand. Ekológia (Bratislava) 22 (2): 119-131.

Krebs H.J. (2001): Ekologia. Wydawnictwo Naukowe PWN, Warszawa.

KRUPA K. (2000): Zbiorowiska szuwarowe okolic Lądka w Nadwarciańskim Parku Krajobrazowym. Roczniki Naukowe PTP „Salamandra” 4: 25-53.

Kuklova M., Kukla J., Schieber B. (2005): Individual and population parameters of Carex pilosa Scop. (Cyperaceae) in four forest sites in Western Carpathians (Slovakia). Polish Journal of Ecology 53: 427-434.

Matuszkiewicz W. (2013): Przewodnik do oznaczania zbiorowisk roślinnych Polski. Wydawnictwo Naukowe PWN, Warszawa.

NiedzióŁKA I., Zuchniarz A. (2006): Analiza energetyczna wybranych rodzajów biomasy pochodzenia roślinnego. MOTROL 8A: 232-237.

OśwIT J. (2000): Metoda przyrodniczej waloryzacji mokradeł i wyniki jej zastosowania w wybranych obiektach. IMUZ, Falenty: 3-32.

Prosiński S. (2003): Chemia drewna. PWRiL, Warszawa.

RiIs T., BigGs B.J.F. (2003): Hydrologic and hydraulic control of macrophyte establishment and performance in streams. Limnology and Oceanography 48: 1488-1497.

Rogalski M., Sawicki B., Bajonko M., Wieczorek A. (2005): Wykorzystanie rodzimych gatunków traw jako odnawialnych źródeł energii. In: M. Ciaciura (ed.). Alternatywne źródła energii. Dobrodziejstwa i zagrożenia. Wyd. Optimex, Szczecin: 15-25.
Rogalski M., Wieczorek A., Szenejko M., KamińsKa A., MıŁeK E. (2008): Możliwości wykorzystania ekstensywnie użytkowanych łąk nadmorskich do celów energetycznych. Łąkarstwo w Polsce (Grassland Science in Poland) 11: 177-184.

StRATEGIA rozwoju energetyki odnawialnej - przyjęta przez Sejm RP 23.08.2001. (2001). Ministerstwo Środowiska, Warszawa.

Trzaskoś M., Kamińska G., Winkler L., Malinowski R. (2005): Walory przyrodnicze zbiorowisk trawiastych wilgotnych i mokrych siedlisk Kostrzyneckiego Rozlewiska. Łąkarstwo w Polsce (Grassland Science in Poland) 8: 193-206.

UstaWA $\mathrm{z}$ października o biokomponentach stosowanych $\mathrm{w}$ paliwach ciekłych i biopaliwach ciekłych (2003). Dz.U. 2003 nr 199 poz. 1934.

Virtanen K., Valpola S. (2011): Energy potential of Finnish peatlands. Geological Survey of Finland 49: 153-161.

Waliszewska B., Janyszek M., Grzelak M., Gawee E. (2013): Characteristic of thermochemical parameters of aboveground parts of selected sedges (Carex L. Cyperaceae). IOSR Journal of Agriculture and Veterinary Science 5: 1-6.

For citation: Grzelak M., Gawet E., Waliszewska B., Janyszek M., Wrońska-Pilarek D., Murawski M., KNiOŁA A. (2016): Floristic and habitat variability, nature and energy value of selected sedge communities. Steciana 20(4): 233-238. doi: 10.12657/ steciana.020.024 